\title{
Carbon-dependent chromate toxicity mechanism in an environmental Arthrobacter isolate
}

\section{Authors: Erin K. Field, John P. Blaskovich, Brent M. Peyton, and Robin Gerlach}

NOTICE: this is the author's version of a work that was accepted for publication in Journal of Hazardous Materials. Changes resulting from the publishing process, such as peer review, editing, corrections, structural formatting, and other quality control mechanisms may not be reflected in this document. Changes may have been made to this work since it was submitted for publication. A definitive version was subsequently published in Journal of Hazardous Materials, VOL\# 355, (August 2018), DOI\#10.1016/j.jhazmat.2018.05.020.

Field, Erin K., John P. Blaskovich, Brent M. Peyton, and Robin Gerlach. "Carbon-Dependent Chromate Toxicity Mechanism in an Environmental Arthrobacter Isolate." Journal of Hazardous Materials 355 (August 2018): 162-169. doi:10.1016/j.jhazmat.2018.05.020.

Made available through Montana State University's ScholarWorks

scholarworks.montana.edu 


\title{
Carbon-dependent chromate toxicity mechanism in an environmental Arthrobacter isolate
}

\author{
Erin K. Field ${ }^{\mathrm{a}, \mathrm{b}, *}$, John P. Blaskovich ${ }^{\mathrm{b}, \mathrm{c}}$, Brent M. Peyton ${ }^{\mathrm{b}, \mathrm{c}}$, Robin Gerlach ${ }^{\mathrm{b}, \mathrm{c}, * *}$ \\ a Department of Biology, East Carolina University, Greenville, NC, 27858, United States \\ b Center for Biofilm Engineering, Montana State University, Bozeman, MT, 59717, United States \\ ${ }^{\mathrm{c}}$ Department of Chemical and Biological Engineering, Montana State University, Bozeman, MT, 59717, United States
}

\begin{abstract}
A B S T R A C T
Arthrobacter spp. are widespread in soil systems and well-known for their $\mathrm{Cr}(\mathrm{VI})$ reduction capabilities making them attractive candidates for in situ bioremediation efforts. Cellulose drives carbon flow in soil systems; yet, most laboratory studies evaluate Arthrobacter-Cr(VI) interactions solely with nutrient-rich media or glucose. This study aims to determine how various cellulose degradation products and biostimulation substrates influence $\mathrm{Cr}$ (VI) toxicity, reduction, and microbial growth of an environmental Arthrobacter sp. isolate. Laboratory culturebased studies suggest there is a carbon-dependent $\mathrm{Cr}(\mathrm{VI})$ toxicity mechanism that affects subsequent $\mathrm{Cr}(\mathrm{VI})$ reduction by strain LLW01. Strain LLW01 could only grow in the presence of, and reduce, $50 \mu \mathrm{M} \mathrm{Cr}(\mathrm{VI}) \mathrm{when}$ glucose or lactate were provided. Compared to lactate, $\mathrm{Cr}(\mathrm{VI})$ was at least 30 -fold and 10 -fold more toxic when ethanol or butyrate was the sole carbon source, respectively. The addition of sulfate mitigated toxicity somewhat, but had no effect on the extent of Cr(VI) reduction. Cell viability studies indicated that a small fraction of cells were viable after 8 days suggesting cell growth and subsequent $\mathrm{Cr}(\mathrm{VI})$ reduction may resume. These results suggest when designing bioremediation strategies with Arthrobacter spp. such as strain LLW01, carbon sources such as glucose and lactate should be considered over ethanol and butyrate.
\end{abstract}

\section{Introduction}

Chromate (Cr(VI)) is a widespread heavy metal contaminant in soil systems [1-7]. It is a known human carcinogen by the US Toxicological Program and the International Agency for Research on Cancer with the US EPA reference dose of $5 \mu \mathrm{g} / \mathrm{kg} / \mathrm{d}$ based on a one year study in rats [8]. The reduction of $\mathrm{Cr}(\mathrm{VI})$ to the less water soluble, less toxic trivalent form ( $\mathrm{Cr}(\mathrm{III})$ ) is therefore advantageous in situ. The microbial reduction of $\mathrm{Cr}(\mathrm{VI})$ to $\mathrm{Cr}(\mathrm{III})$ is one potential mechanism to remediate contaminated soil systems; however, microbes must be capable of surviving in the presence of this contaminant to contribute to its remediation.

Arthrobacter spp. are ubiquitous in soil systems $[9,10]$ and are well known for their high tolerance to a variety of toxic compounds including $\mathrm{Cr}(\mathrm{VI})$. Arthrobacter spp. mitigate toxicity through the use of cellular efflux pumps $[5,11]$, biosorption to extracellular polymeric substances produced by the cells $[12,13]$, through the direct reduction of $\mathrm{Cr}(\mathrm{VI})$ to its less toxic form $\mathrm{Cr}(\mathrm{III})[8,14,15]$, and through the indirect reduction of $\mathrm{Cr}(\mathrm{VI})$ to $\mathrm{Cr}(\mathrm{III})$ due to aerobic microbial metabolism [16]. These characteristics make Arthrobacter spp. attractive candidates for a wide variety of environmental applications including $\mathrm{Cr}(\mathrm{VI})$ remediation efforts as biosorbents $[13,17]$ and biostimulation targets for metal reduction [18-20]. The widespread presence of Arthrobacter spp. at known metal contaminated sites [3-9] and a wide variety of other soil systems [1,2] suggests that if microbial growth is stimulated to promote chromate reduction, Arthrobacter spp. may be significant contributors to this process.

Soil systems are complex and microbial $\mathrm{Cr}(\mathrm{VI})$ reduction in situ is affected by a variety of conditions including soil $\mathrm{pH}$, moisture, oxygen, redox potential, organic matter, the availability of other electron donors and acceptors, and the microbial community structure $[8,16,21,22]$. Cellulose is a primary source of carbon in terrestrial soil systems and therefore is an important driver in carbon cycling in situ [23-25] and ultimately in microbial Cr(VI) reduction. It has been wellestablished that the carbon source available can influence both the microbial community structure and a community's ability to reduce $\mathrm{Cr}$ (VI) [26-30]. And yet, laboratory studies have focused largely on $\mathrm{Cr}$ (VI)-resistance and reduction capabilities of Arthrobacter spp. grown on nutrient-rich media with glucose as the primary carbon source $[2,3,18,20,31,32]$. As glucose is rapidly consumed by microorganisms in the environment due to its high energy yield, there are a variety of 


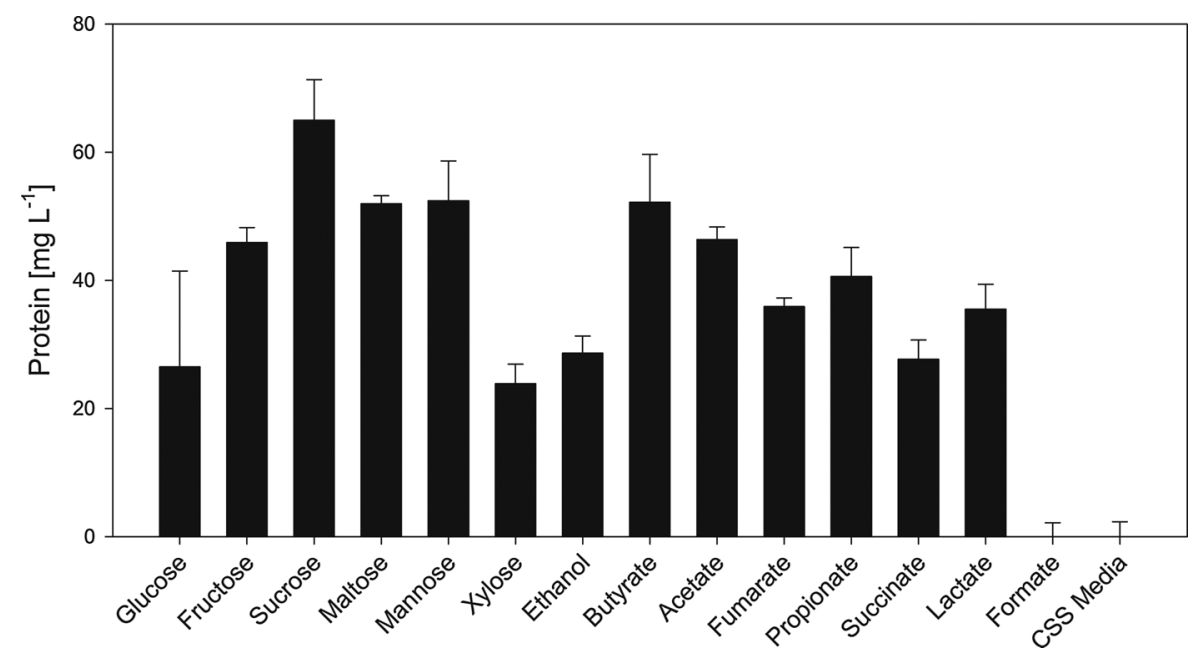

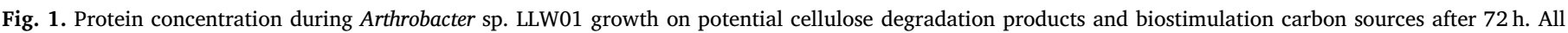
carbon sources were normalized to $15 \mathrm{mM}$ carbon. Error bars represent \pm one standard deviation $(\mathrm{n}=2)$.

other cellulose degradation products which would also be readily available for consumption. However, these have not been well addressed in laboratory studies. Similarly, in environments where organic carbon is added to stimulate microbial contaminant remediation [33-38] it is imperative to first understand how these organisms respond under environmentally-relevant conditions.

The Department of Energy (DOE) is responsible for a number of $\mathrm{Cr}$ (VI)-contaminated sites in which Arthrobacter spp. have been found $[2,39,40]$. These include Low-Level Waste (LLW) sites which contain cellulosic waste often in the form of cardboard, mop heads, and paper towels contaminated with heavy metals and radionuclides with $\mathrm{Cr}(\mathrm{VI})$ concentrations of approximately $50 \mu \mathrm{M} \mathrm{Cr}(\mathrm{VI})[41,42]$. This cellulosic waste is the primary source of carbon in these systems and can be degraded by microorganisms to other carbon sources including sugars, organic acids, and alcohols [43-45]. The fate of metals such as chromium in these sites is largely unknown as chromium can be released during this process enhancing transport or it can be reduced by microorganisms to a less soluble form decreasing transport. Previously, Arthrobacter-related 16S rRNA sequences were identified in a simulated LLW site from the Idaho National Laboratory [40] and an Arthrobacter sp. isolate was subsequently obtained through laboratory microcosm experiments. This study aimed to evaluate how various cellulose degradation products which may be present in LLW sites as well as other soil systems affect growth, $\mathrm{Cr}(\mathrm{VI})$ toxicity, and subsequent $\mathrm{Cr}(\mathrm{VI})$ reduction by an environmental isolate, Arthrobacter sp. strain LLW01. These laboratory studies address fundamental interaction between $\mathrm{Cr}$ (VI) and strain LLW01 when carbon metabolism varied and can be used to better predict how Arthrobacter spp. may contribute to $\mathrm{Cr}(\mathrm{VI})$ reduction in LLW sites and other soil systems.

\section{Materials and methods}

\subsection{Experimental growth conditions}

Arthrobacter sp. LLW01 was isolated from a soil sample collected from a simulated LLW site at the Idaho National Laboratory [40] (Supplemental Methods Isolation \& Identification). Strain LLW01 was grown aerobically from frozen glycerol stocks in Tryptic Soy Broth (BD Difco, Franklin Lakes, $\mathrm{NJ})$ at room temperature $\left(22 \pm 2{ }^{\circ} \mathrm{C}\right)$ and shaken at $150 \mathrm{rpm}$ for $20 \mathrm{~h}$ to reach late exponential phase. The culture was centrifuged, washed and resuspended in a defined, carbon-free medium three times. This carbon-free (CF) medium simulates the groundwater chemistry at the Idaho National Laboratory and was modified from VanEngelen et al. [46] (Table S1). Briefly, this medium contained the following per L of medium: $80 \mathrm{mg} \mathrm{NaCl}, 26 \mathrm{mg} \mathrm{K}_{2} \mathrm{HPO}_{4}, 3.35 \mathrm{~g}$ PIPES Buffer, $0.6 \mathrm{mg} \mathrm{KCl}, 0.4 \mathrm{mg} \mathrm{KOH}, 12.7 \mathrm{mg} \mathrm{Na}_{2} \mathrm{SO}_{4}, 3.5 \mathrm{mg} \mathrm{CaO}$, and $7.5 \mathrm{mg} \mathrm{MgCl} 2 * 6 \mathrm{H}_{2} \mathrm{O}$ amended with $5 \mathrm{ml}$ of Wolfe's vitamin solution and $1 \mathrm{ml}$ SL-4 trace elements solution [47] (Table S1). The final resuspended culture was diluted in microtiter plates with sterile medium to normalize starting cell densities to an optical density of approximately 0.2 at $600 \mathrm{~nm}\left(\mathrm{OD}_{600}\right)$ (corresponding to $3.7 \times 10^{8}-4.7 \times 10^{8}$

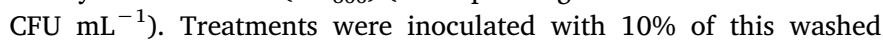
culture. Carbon source was added separately where indicated.

\subsection{Batch studies}

\subsubsection{Carbon source utilization study}

To identify which carbon sources strain LLW01 can utilize for growth, a study was performed with fourteen different substrates. The following carbon sources representing a variety of potential cellulose degradation products were used: Glucose (dextrose), fructose, maltose, mannose, sucrose, xylose, sodium acetate, sodium butyrate, sodium formate, sodium fumarate, sodium propionate, sodium succinate, sodium lactate (60\% w/w lactate syrup) and ethanol (EtOH). In sterile, 24-well microtiter plates, duplicate wells were set up for each carbon source ( $15 \mathrm{mM}$ carbon final concentration), CF medium, and strain LLW01 for a total volume of $2.5 \mathrm{~mL}$ per well. Carbon concentrations were chosen based on previous metal toxicity studies [46] and ensure carbon is not limiting in the experiments. Duplicate cell-free and carbon-free control wells were included. Plates were shaken at $150 \mathrm{rpm}$ at room temperature $\left(22 \pm 2{ }^{\circ} \mathrm{C}\right)$ and absorbance measurements were taken at $600 \mathrm{~nm}$ after $72 \mathrm{~h}$. Protein concentrations after $72 \mathrm{~h}$ were determined as well. The time frame for this experiment was chosen based on preliminary growth curves with $15 \mathrm{mM}$ glucose in which stationary phase had been reached.

\subsection{2. $\operatorname{Cr}(V I)$ toxicity studies}

Based on the results obtained in the 24-well plate carbon source screening study, glucose, ethanol, lactate, and butyrate were used in $\mathrm{Cr}$ (VI) toxicity experiments as each represents different types of potential cellulose degradation products (i.e. sugars, organic acids and alcohols). A concentration of $50 \mu \mathrm{M} \mathrm{Cr}(\mathrm{VI})$ was used as it is close to the concentration under enrichment conditions, as well as those found in LLW sites [41,42]. These studies were carried out aerobically in $25 \mathrm{~mL}$ screw cap test tubes in triplicate. For each carbon source, treatments were set up containing CF medium, $15 \mathrm{mM}$ carbon, and strain LLW01. Appropriate cell-free and carbon-free control treatments were also set up. Tubes were shaken at $150 \mathrm{rpm}$ at room temperature $\left(22 \pm 2{ }^{\circ} \mathrm{C}\right)$. 

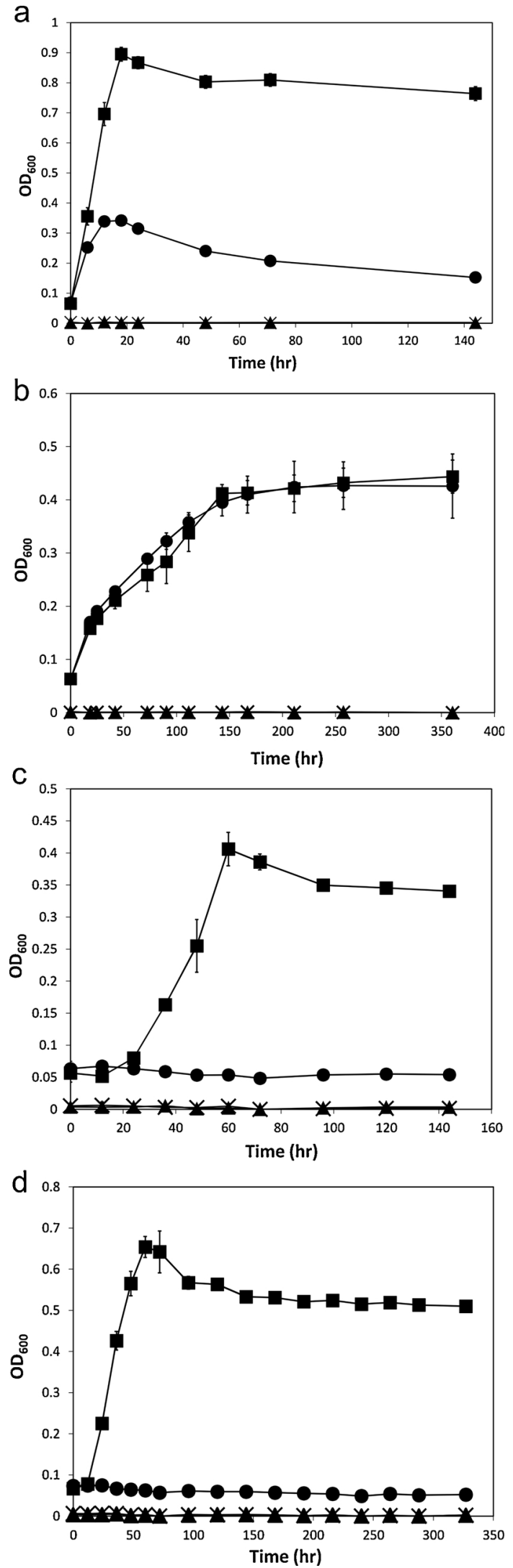

Fig. 2. Growth of Arthrobacter sp. LLW01 when (a) glucose, (b) lactate, (c) ethanol and (d) butyrate were the sole carbon sources in the (๑) presence and

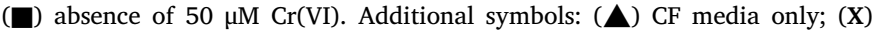
Carbon source only. Error bars represent \pm one standard deviation $(n=3)$ and are smaller than the symbols where not visible.
Absorbance measurements at $600 \mathrm{~nm}$ and samples for $\mathrm{Cr}(\mathrm{VI})$ analysis were taken over time.

\subsubsection{Cell viability studies}

Cell viability studies were conducted to determine whether $\mathrm{Cr}(\mathrm{VI})$ has a bactericidal or bacteriostatic effect on strain LLW01. For the cell viability studies treatments were scaled up to $50 \mathrm{~mL}$ flasks. Treatments either contained glucose or ethanol as each represent a low and high $\mathrm{Cr}$ (VI) toxicity carbon source, respectively. Lactate was not evaluated as no loss in cell densities, as measured by $600 \mathrm{~nm}$, was observed in the presence of $\mathrm{Cr}(\mathrm{VI})$. Flasks were shaken at $150 \mathrm{rpm}$ at room temperature $\left(22 \pm 2{ }^{\circ} \mathrm{C}\right)$ and over time samples were taken for $\mathrm{Cr}(\mathrm{VI})$ analysis, absorbance measurements at $600 \mathrm{~nm}$, and plate counts. Plate counts were conducted by serially diluting the sample in sterile phosphate buffered saline solution. Dilutions were used for drop plating in which 5 replicates of $10 \mu \mathrm{L}$ were pipetted onto tryptic soy agar (TSA) plates for each dilution. These plates were incubated at room temperature $\left(22 \pm 2{ }^{\circ} \mathrm{C}\right)$ for $24 \mathrm{~h}$ and colonies were counted and averaged to cal-

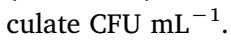

\subsubsection{Sulfate exclusion study}

$\mathrm{Cr}(\mathrm{VI})$ in the form of $\mathrm{CrO}_{4}{ }^{2-}$ has been described to enter the cell through the same transport system as sulfate $\left(\mathrm{SO}_{4}{ }^{2-}\right)$ [48]. In an attempt to mitigate toxicity through competitively excluding $\mathrm{Cr}(\mathrm{VI})$ from the cell, $\mathrm{SO}_{4}{ }^{2-}$ was added to the system in excess $\left(100: 1 \mathrm{SO}_{4}{ }^{2-}\right.$ to $\mathrm{CrO}_{4}{ }^{2-} ; 5 \mathrm{mM}$ sulfate final concentration). Glucose was the provided carbon source and the same protocol as listed in the $\mathrm{Cr}(\mathrm{VI})$ toxicity batch studies was followed. Glucose was used as the sole carbon source as strain LLW01 was capable of growing in the presence of $50 \mu \mathrm{M} \mathrm{Cr}$ (VI), but at a reduced growth rate and maximum OD suggesting these cells were most likely to respond to mitigation methods and would have the greatest measurable response. Appropriate cell-free and carbon-free treatments were set up as well. Tubes were shaken at $150 \mathrm{rpm}$ at room temperature $\left(22 \pm 2{ }^{\circ} \mathrm{C}\right)$. Absorbance measurements at $600 \mathrm{~nm}$ and samples for $\mathrm{Cr}(\mathrm{VI})$ analysis were taken over time.

\subsection{Analytical methods}

\subsection{1. $\operatorname{Cr}(V I)$ quantification}

$\mathrm{Cr}(\mathrm{VI})$ concentrations were determined spectrophotometrically using the diphenylcarbazide assay as described by Nyman et al. [49]. In short, $150 \mu \mathrm{L}$ of the sample was added to $50 \mu \mathrm{L}$ of $0.8 \mathrm{~N} \mathrm{H}_{2} \mathrm{SO}_{4}$ in a 96 well microtiter plate followed by the addition of $20 \mu \mathrm{L}$ of $0.25 \% 1,5-$ diphenylcarbazide (Sigma-Aldrich, St. Louis, MO) in 100\% acetone. Assay blanks were prepared by the addition of $20 \mu \mathrm{L}$ of $100 \%$ acetone without 1,5-diphenylcarbazide. Absorbance was measured at $540 \mathrm{~nm}$, adjusted with corresponding assay blanks and compared to standards made from a $\mathrm{K}_{2} \mathrm{CrO}_{4}$ stock solution (Ricca Chemical Company, Arlington, TX).

\subsubsection{Protein quantification}

A colorimetric protein assay, modified from Viamajala et al. [50], was used to estimate total protein. Briefly, $200 \mu \mathrm{L} 1 \mathrm{~N} \mathrm{NaOH}$ was added to $200 \mu \mathrm{L}$ of sample and digested in a hot water bath at $90^{\circ} \mathrm{C}$ for $10 \mathrm{~min}$. After samples cooled, $28 \mu \mathrm{L}$ of a $6: 10 \mathrm{v} / \mathrm{v} \mathrm{HCl}$ solution was added. Triplicate technical replicates of $50 \mu \mathrm{L}$ aliquots per sample were added to a 96-well plate. Coomassie reagent (Pierce, Rockford, IL) was added to each of the wells $(150 \mu \mathrm{L})$ and allowed to react for $15 \mathrm{~min}$ after which absorbance readings were taken at $595 \mathrm{~nm}$. Absorbance measurements were compared to bovine serum albumin standards and technical replicate protein concentrations were averaged for each sample to provide final protein concentrations.

\subsection{3. $\mathrm{Cr}(\mathrm{VI})$ reduction rates}

First order reduction rates with respect to $\mathrm{Cr}(\mathrm{VI})$ concentration were estimated using the following model 
Table 1

Growth Parameters of Arthrobacter sp. LLW01 in the Presence and Absence of $50 \mu \mathrm{M}$ Cr(VI).

\begin{tabular}{|c|c|c|c|c|c|}
\hline \multirow[t]{2}{*}{ Carbon Source } & \multicolumn{2}{|l|}{ Growth Rate $^{\mathrm{a}}$} & \multicolumn{2}{|l|}{ Lag Time ${ }^{\mathrm{b}}$} & \multirow[t]{2}{*}{ Estimated IC50 $[\mu \mathrm{M}]$} \\
\hline & Carbon + Strain LLW01 $\left[\mathrm{hr}^{-1}\right]$ & 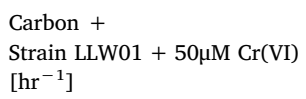 & $\begin{array}{l}\text { Carbon + Strain LLW01 } \\
\text { [hr] }\end{array}$ & 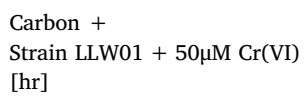 & \\
\hline Glucose & $0.140 \pm 0.006$ & $0.091 \pm 0.0055$ & 0.0 & 0.0 & $48.0 \pm 1.7$ \\
\hline Lactate & $0.013 \pm 0.0005$ & $0.013 \pm 0.0005$ & 0.0 & 0.0 & $170.0 \pm 2.2$ \\
\hline Butyrate & $0.044 \pm 0.0021$ & NG & $13.1 \pm 2.20$ & NG & $9.0 \pm 1.0$ \\
\hline Ethanol & $0.032 \pm 0.0145$ & NG & $12.0 \pm 0.02$ & NG & BDL \\
\hline
\end{tabular}

NG; No Growth Observed.

IC50; $\mathrm{Cr}(\mathrm{VI})$ concentration at which half the maximal inhibition of cell growth was observed.

BDL; Below the detection limit (5 $\mu \mathrm{M} \mathrm{Cr}(\mathrm{VI})$ ).

a Error reported for at least three separate, biological replicate studies.

b Error reported for three biological replicates within one study.

$\mathrm{cCr}(\mathrm{VI})=\mathrm{cCr}(\mathrm{VI})_{\mathrm{o}} * \exp ^{-\mathrm{kt}}$

in which $\mathrm{cCr}(\mathrm{VI})_{\mathrm{o}}$ is the initial $\mathrm{Cr}(\mathrm{VI})$ concentration at time zero, $\mathrm{cCr}$ (VI) is the $\mathrm{Cr}(\mathrm{VI})$ concentration at time (t) and $\mathrm{k}$ is the first order rate coefficient. Data were fitted to the model using a non-linear regression scheme by minimizing the sum of the squared residuals.

\subsubsection{IC50 calculations}

In this study, IC50 is defined as the $\mathrm{Cr}(\mathrm{VI})$ concentration that resulted in half the maximal cell growth as measured by absorbance at $600 \mathrm{~nm}$. Strain LLW01 was grown in the presence of increasing $\mathrm{Cr}(\mathrm{VI})$ concentrations in the presence of each carbon source and the maximum absorbance was measured and compared to the chromate-free controls. Estimated IC50s were calculated using a linear regression equation determined by $\log \mathrm{Cr}(\mathrm{VI})$ concentrations versus percent growth inhibition (as measured by differences in maximum optical densities between the $\mathrm{Cr}(\mathrm{VI})$-containing and $\mathrm{Cr}(\mathrm{VI})$-free treatments).

\subsubsection{Lag time calculations}

Lag times were estimated using a modified Gompertz equation [51] and optical density data (Eq. (2)) where lag time $(\gamma)$ in which $N$ is the optical density when growth is first observed at time $(t), N_{O}$ is the optical density at time zero, $\mu \max$ is the maximum growth rate, and $A$ is equal to $\ln \left(N_{s t} / N_{O}\right)$ where $N_{s t}$ is the optical density when the culture reaches steady state.

$\ln \frac{N}{N o}=A \exp \left\{-\exp \left[\frac{\mu \max ^{*} e}{A}(\gamma-t)+1\right]\right\}$

\section{Results and discussion}

\subsection{Carbon Source Utilization Capabilities}

Strain LLW01 utilized a wide variety of carbon sources as an increase in protein was observed for 13 of the 14 potential cellulose degradation products after $72 \mathrm{~h}$ (Fig. 1). There was variability in total protein accumulated depending on the carbon source indicating strain LLW01 likely obtained more energy from some carbon sources (such as sucrose and butyrate) compared to others (such as ethanol or xylose) during this time period. No measurable growth was observed after $72 \mathrm{~h}$ when formate was the sole carbon source available. These cellulose degradation products are likely present in LLW sites and other soil environments suggesting strain LLW01 may be capable of utilizing any of these carbon sources when available.

\subsection{Influence of Carbon Source on Growth in the Presence of $\mathrm{Cr}(\mathrm{VI})$}

Glucose, lactate, butyrate, and ethanol were used as representative carbon sources of various types of potential cellulose degradation products as well as possible energy sources for biostimulation at contaminated sites (i.e., sugars, organic acids, and alcohols). If either glucose or lactate were provided as the sole carbon source, strain LLW01 grew in the presence of $50 \mu \mathrm{M} \mathrm{Cr}(\mathrm{VI})$ (Fig. 2a and b). This is consistent with the conditions under which the organism was isolated. However, if ethanol or butyrate were the sole carbon source, no growth of strain LLW01 was observed in the presence of $50 \mu \mathrm{M} \mathrm{Cr}(\mathrm{VI})$ (Fig. 2c and $\mathrm{d}$ ), even after 38 days (data not shown). $\mathrm{Cr}(\mathrm{VI})$ was more toxic to strain LLW01 in the presence of glucose compared to lactate as evident by reduced extent of growth (maximum $\mathrm{OD}_{600}$ ), slower growth rate, and a lower IC50 for $\mathrm{Cr}(\mathrm{VI})$ (Table 1, Fig. S1-S4). In comparison, there was no measurable decrease in the maximum $\mathrm{OD}_{600}$ or growth rate of strain LLW01 when lactate and $50 \mu \mathrm{M} \mathrm{Cr}(\mathrm{VI})$ were present. The IC50 for $\mathrm{Cr}(\mathrm{VI})$ was also approximately three times higher when lactate was the sole carbon source compared to glucose. Cr(VI) toxicity to strain LLW01 did not correlate with growth rate. In the absence of $\mathrm{Cr}(\mathrm{VI})$, the highest growth rate observed was in the presence of glucose, while the lowest was in the presence of lactate (Table 1 ).

$\mathrm{Cr}(\mathrm{VI})$ concentrations below $50 \mu \mathrm{M} \mathrm{Cr}(\mathrm{VI})$ were evaluated to determine at which concentration $\mathrm{Cr}(\mathrm{VI})$ becomes toxic to strain LLW01 when either ethanol or butyrate served as the sole carbon source (Fig. S3, S4). Growth was measurable only when $\mathrm{Cr}(\mathrm{VI})$ concentrations were below $5 \mu \mathrm{M} \mathrm{Cr}(\mathrm{VI})$ in the presence of ethanol (Fig. S3). The results indicate that the IC50 is less than $5 \mu \mathrm{M} \mathrm{Cr}(\mathrm{VI})$ demonstrating that $\mathrm{Cr}$ (VI) is over 30-fold more toxic to strain LLW01 in the presence of ethanol compared to lactate. Butyrate was less toxic than ethanol as only a $28 \%$ decrease in max OD was observed in the presence of $5 \mu \mathrm{M}$ $\mathrm{Cr}(\mathrm{VI})$ and no measurable decrease in growth was observed below this concentration. Overall, these results demonstrate that $\mathrm{Cr}(\mathrm{VI})$ is significantly more toxic to strain LLW01 when ethanol or butyrate is the sole carbon source compared to glucose or lactate and suggests there is a strong carbon-dependent chromate toxicity mechanism in Arthrobacter sp. LLW01.

To our knowledge, this is the first observation of a carbon-dependent chromate toxicity response in an Arthrobacter isolate. While the identification of the specific toxicity mechanism or mechanisms is beyond the scope of this study, we can develop hypotheses based on our findings. Evidence of a carbon-dependent toxicity mechanism, rather than general cell damage by $\mathrm{Cr}(\mathrm{VI})$, was suggested when a decrease in cell viability was only observed if both ethanol and $\operatorname{Cr}(\mathrm{VI})$ were present, indicating their combined presence was necessary for $\mathrm{Cr}(\mathrm{VI})$ toxicity. It is possible that the uptake of ethanol by strain LLW01 increased the uptake of $\mathrm{Cr}(\mathrm{VI})$ as well leading to this increased toxicity; however, no measurable decrease in $\mathrm{Cr}(\mathrm{VI})$ occurred in these treatments. It could be possible that strain LLW01 cannot gain enough energy from carbon sources such as butyrate and ethanol to both grow and mitigate toxicity concurrently, which would support the observation that some of the 

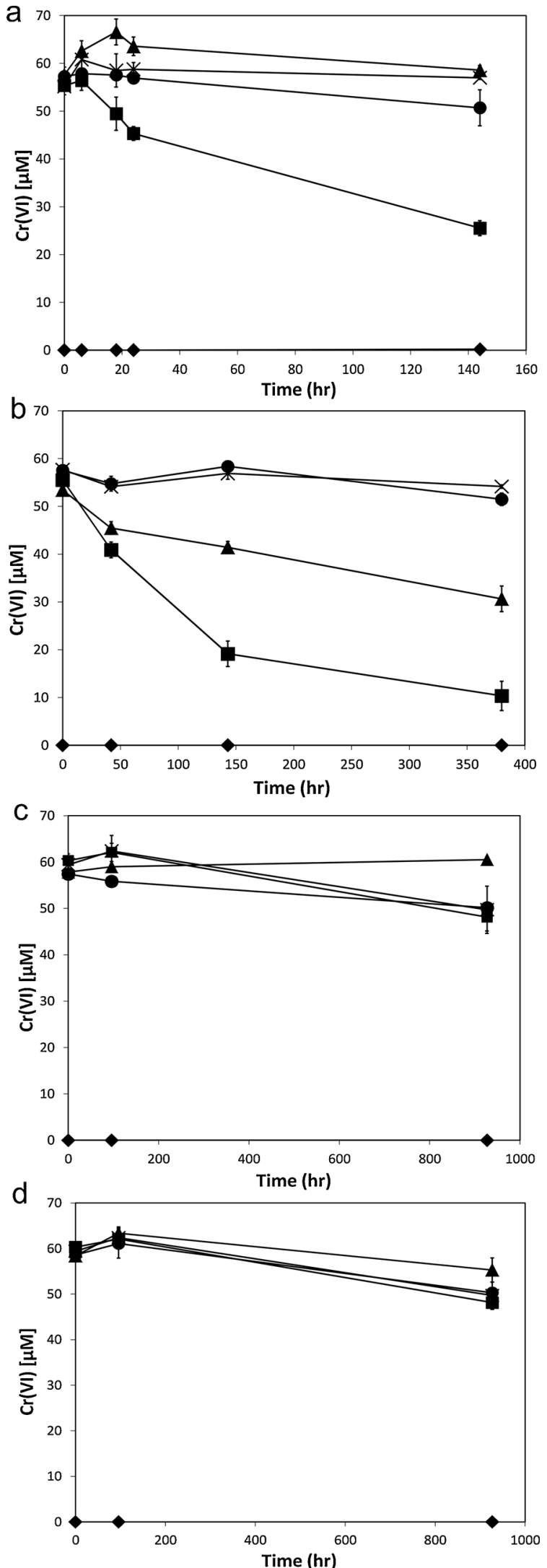

Fig. 3. Cr(VI) concentrations over time when (a) glucose, (b) lactate, (c) ethanol, and (d) butyrate were the sole carbon sources available to Arthrobacter sp. LLW01 in the $(\square)$ presence of $50 \mu \mathrm{M} \mathrm{Cr}(\mathrm{VI})$. Additional symbols: ( $\downarrow$ ) CF media only; ( $)$ Arthrobacter sp. LLW01 and $50 \mu \mathrm{M} \mathrm{Cr}(\mathrm{VI})$ only; (A) carbon source and $50 \mu \mathrm{M} \mathrm{Cr}$ (VI) only; (X) $50 \mu \mathrm{M} \mathrm{Cr}(\mathrm{VI})$ only. Error bars represent \pm one standard deviation $(n=3)$ and are smaller than the symbols where not visible. cells were viable, but did not grow under the conditions presented. This is common in aerobic systems where $\mathrm{Cr}(\mathrm{VI})$ reduction is coupled to carbon oxidation of organic compounds [16] and the transfer of electrons to $\mathrm{Cr}(\mathrm{VI})$ is inefficient. However, this toxicity can be mitigated if excess carbon is available [16]. It is unlikely cells were energy-limited in this study as excess carbon was added in all experiments at a minimum ratio of 100:1 (carbon to $\mathrm{Cr}(\mathrm{VI})$ ). When ethanol was present and $\mathrm{Cr}(\mathrm{VI})$ concentrations were as low as $5 \mu \mathrm{M}$ and the carbon to $\mathrm{Cr}(\mathrm{VI})$ ratio was more than 1000:1, cell growth still did not occur. Additionally, the highest protein concentrations from the carbon utilization study of these four carbon sources was measured for butyrate $(52.18 \mathrm{mg} / \mathrm{L})$ which was significantly higher than both ethanol (t-test; $\mathrm{p}=0.0068$ ) and glucose (t-test; $\mathrm{p}=0.0266)$. Therefore, efficiency in carbon metabolism of butyrate cannot solely explain the higher $\mathrm{Cr}(\mathrm{VI})$ toxicity. It is possible that the metabolism of EtOH and butyrate increase the uptake of $\mathrm{Cr}(\mathrm{VI})$ by cells which leads to this higher toxicity, but no measurable decrease in $\mathrm{Cr}(\mathrm{VI})$ concentration was measured. While we did not conduct any studies to identify the specific toxicity mechanism, toxicity is more likely due to the direct interaction between $\mathrm{Cr}(\mathrm{VI})$ and cellular enzymes, such as NADH-dependent enzymes, used in specific carbon metabolism pathways. Similar interactions have been described for other metals and cellular enzymes such as in the case of aerobic PQQ-dependent toxicity of uranium to a Pseudomonas sp. [46,52] suggesting that $\mathrm{Cr}(\mathrm{VI})$-enzyme interactions could be potential mechanisms in strain LLW01 as well. Future studies will aim to identify the specific mechanism or mechanisms that lead to this toxicity.

\subsection{Influence of Carbon Source on Cr(VI) Reduction}

There was an association between $\mathrm{Cr}(\mathrm{VI})$ reduction and the capability of strain LLW01 to grow in the presence of $50 \mu \mathrm{M} \mathrm{Cr}(\mathrm{VI})$. When glucose was the sole carbon source, strain LLW01 was capable of growth and $\mathrm{Cr}(\mathrm{VI})$ reduction was measured decreasing from $50 \mu \mathrm{M} \mathrm{Cr}$ (VI) to $25 \mu \mathrm{M} \mathrm{Cr}(\mathrm{VI})$ within $144 \mathrm{~h}$ (Fig. 3a); the calculated first order reduction rate coefficient was $4.4 \mathrm{E}-03 \pm 8.8 \mathrm{E}-04 \mathrm{~h}^{-1}(\mathrm{n}=3)$. Most of this reduction occurred after $18 \mathrm{~h}$ when the cells were in stationary phase indicating the cells first grew exponentially then $\mathrm{Cr}(\mathrm{VI})$ reduction began.

In the presence of lactate and strain LLW01 Cr(VI) concentrations decreased by $80 \%$ after $380 \mathrm{~h}$ (Fig. 3b). However, there was significant abiotic $\mathrm{Cr}(\mathrm{VI})$ reduction in controls containing lactate and $\mathrm{Cr}(\mathrm{VI})$ suggesting that half of the reduction in $\mathrm{Cr}(\mathrm{VI})$ concentration was due to abiotic reduction. This was likely due to the formation of a lactate-Cr (VI) complex or sodium lactate syrup impurities that were acting as additional reductants as Brodie et al. [36] observed. In controls with lactate, approximately $40 \%$ of the $\mathrm{Cr}(\mathrm{VI})$ present was no longer measurable using the DPC assay and this decrease was observed consistently over multiple studies. Therefore, the net reduction attributed to the presence of strain LLW01 was about $40 \%$ or $20 \mu \mathrm{M} \mathrm{Cr}(\mathrm{VI})$ over the $380 \mathrm{~h}$ period, most of which occurred in the first $160 \mathrm{~h}$ while the cells were in exponential phase. This contrasts with strain LLW01 grown with glucose when $\mathrm{Cr}(\mathrm{VI})$ was reduced during stationary phase. The calculated first order $\mathrm{Cr}(\mathrm{VI})$ reduction rate coefficient with lactate was $5.0 \mathrm{E}-03 \pm 1.2 \mathrm{E}-03 \mathrm{~h}^{-1}$. Therefore, $\mathrm{Cr}(\mathrm{VI})$ reduction rates were not significantly different (t-test, $\mathrm{p}=0.7037$ ) regardless of whether glucose or lactate were present but there was a difference in the time that had passed before $\mathrm{Cr}(\mathrm{VI})$ reduction began. When either butyrate or ethanol were the sole carbon sources, no significant reduction of $\mathrm{Cr}(\mathrm{VI})$ was measured over a period of 38 days (Fig. 3c and d). ICP-MS analyses suggest that the measured decrease in $\mathrm{Cr}(\mathrm{VI})$ concentration was due to the reduction of $\mathrm{Cr}(\mathrm{VI})$, rather than biosorption or general cellular uptake (Fig. S5) indicating strain LLW01 is capable of contributing to $\mathrm{Cr}$ (VI) reduction, likely forming $\mathrm{Cr}(\mathrm{III})$ [53] under the provided conditions. It is possible $\mathrm{Cr}(\mathrm{VI})$ was reduced to soluble organo- $\mathrm{Cr}(\mathrm{III})$ products as there was no measurable difference in the filtered total $\mathrm{Cr}$ over the course of the experiments $[54,55]$. 
Reduction of $\mathrm{Cr}(\mathrm{VI})$ occurred only when Arthrobacter sp. LLW01 grew in this study suggesting $\mathrm{Cr}(\mathrm{VI})$ reduction and cell growth was associated. The use of a variety of carbon sources allowed us to observe a host of complex responses that would not be possible by using glucose alone. While $\mathrm{Cr}(\mathrm{VI})$ reduction occurred under many conditions, to observe any measurable growth when ethanol was present, the $\mathrm{Cr}(\mathrm{VI})$ concentration had to be below $5 \mu \mathrm{M} \mathrm{Cr}(\mathrm{VI})$. This concentration is close to the U.S. EPA Drinking Water Standard of $0.1 \mathrm{mg}$ total $\mathrm{Cr} \mathrm{L}^{-1}$ (100 ppb or approximately $2 \mu \mathrm{M} \mathrm{Cr}$ ) (Environmental Protection Agency, 2016), and above the newly adopted maximum contaminant level for chromium $(10 \mathrm{ppb})$ in the State of California (State Water Resources Control Board, California Environmental Protection Agency, 2016). Therefore, bioremediation efforts with strain LLW01 would be ineffective if ethanol or butyrate were supplied to enhance $\mathrm{Cr}(\mathrm{VI})$ reduction. However, if glucose or lactate were supplied then strain LLW01 may be able to contribute to the in situ remediation of $\mathrm{Cr}(\mathrm{VI})$ more effectively.

\section{4. $\operatorname{Cr}(V I)$ Toxicity Mitigation by Sulfate}

Chromate can be taken up by the cell via the same mechanism as sulfate [48] and therefore, it may be possible to mitigate toxicity of chromate via competitive exclusion by sulfate. In this study, the addition of excess sulfate in the presence of $\mathrm{Cr}(\mathrm{VI})$ led to an increase in cell densities, but only mitigated toxicity to a small extent (Fig. 4). The maximum $\mathrm{OD}_{600}$ in the presence of $5 \mathrm{mM} \mathrm{SO}_{4}{ }^{2-}$ increased $18 \%$ compared to when $\mathrm{SO}_{4}{ }^{2-}$ was absent. This increase in growth was still only half the maximum growth measured in the absence of $\mathrm{Cr}(\mathrm{VI}) . \mathrm{Cr}(\mathrm{VI})$ reduction by strain LLW01 was not significantly different with the addition of $5 \mathrm{mM} \mathrm{SO}_{4}{ }^{2-}$ (Fig. S6). Overall, these results indicate that the addition of excess $\mathrm{SO}_{4}{ }^{2-}$ mitigated $\mathrm{Cr}(\mathrm{VI})$ toxicity to a small extent, but no difference in $\mathrm{Cr}(\mathrm{VI})$ reduction was observed (Fig. S4). It also suggests that potential machinery in sulfate transport is not likely playing a role in $\mathrm{Cr}(\mathrm{VI})$ toxicity to strain LLW01 observed here and introduces questions about whether competitive exclusion, by sulfate or other soil constituents, will aid in bioremediation efforts by strain LLW01.

\subsection{Cell Viability in the Presence of $\mathrm{Cr}(\mathrm{VI})$}

A cell viability study with ethanol as the sole carbon source was conducted to determine whether the lack of growth by strain LLW01 in the presence of $\mathrm{Cr}(\mathrm{VI})$ was due to a bactericidal (causing cell death) or

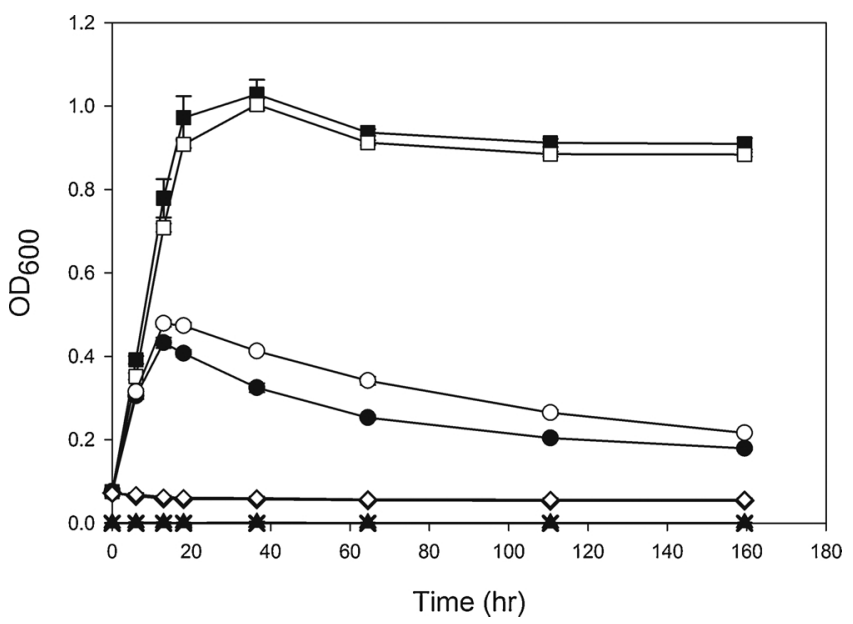

Fig. 4. Chromate toxicity mitigation by the addition of excess sulfate. Growth of Arthrobacter sp. LLW01 with glucose in the $(\bullet, O)$ presence and $(\square, \square)$ absence of $50 \mu \mathrm{M} \mathrm{Cr}(\mathrm{VI})$. Open symbols indicate the additional presence of $5 \mathrm{mM}$ sulfate $\left(\mathrm{SO}_{4}{ }^{2-}\right)$. Additional symbols: $(\mathbf{\Delta}) \mathrm{CF}$ medium only; $(\bullet)$ Arthrobacter sp. LLW01 only; (X) Glucose only. Error bars represent \pm one standard deviation $(n=3)$ and are smaller than the symbols where not visible.

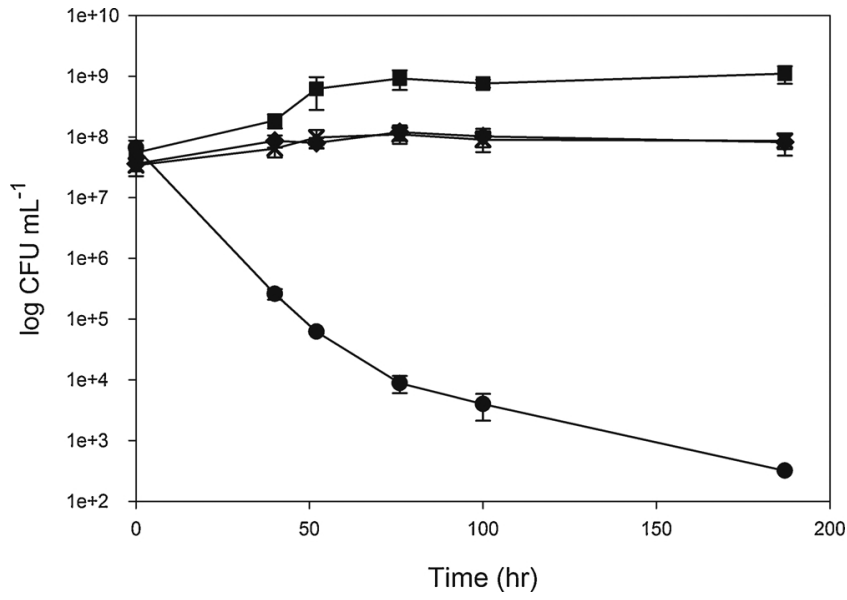

Fig. 5. Cell viability of Arthrobacter sp. LLW01 when ethanol (EtOH) was the sole carbon source in the (O) presence and ( $\square$ ) absence of $50 \mu \mathrm{M} \mathrm{Cr}(\mathrm{VI})$. Additional symbols: ( $\bullet$ Arthrobacter sp. LLW01; (X) Arthrobacter sp. LLW01 and $50 \mu \mathrm{M} \mathrm{Cr}(\mathrm{VI})$. Plate count data representing cell viability are reported as log $\mathrm{CFU} \mathrm{mL}^{-1}$. Error bars represent \pm one standard deviation $(\mathrm{n}=5)$ and are smaller than the symbols where not visible.

bacteriostatic (causing growth inhibition) response to $\mathrm{Cr}(\mathrm{VI})$. As ethanol had the greatest effect on chromate toxicity, it was used in this cell viability study. Results indicate that while the majority of cells were no longer viable, some cells from the treatment containing ethanol, strain LLW01, and $50 \mu \mathrm{M} \mathrm{Cr}(\mathrm{VI})$ remained viable after $187 \mathrm{~h}\left(3.2 \times 10^{2}\right.$ $\mathrm{CFU} \mathrm{mL}{ }^{-1}$, Fig. 5). These results indicate the lack of cell growth and $\mathrm{Cr}$ (VI) reduction may be reversible even though an approximate fiveorder magnitude loss of cell viability was observed after 8 days. This suggests that a switch to a more favorable carbon source either intentionally through biostimulation efforts or due to the production of additional cellulose degradation products in situ could stimulate the growth of strain LLW01 and subsequent reduction of $\mathrm{Cr}(\mathrm{VI})$. Notably, this decrease in cell viability was only observed when both ethanol and $50 \mu \mathrm{M} \mathrm{Cr}(\mathrm{VI})$ were present as there was no significant change in cell viability in the carbon-free control containing strain LLW01 and $50 \mu \mathrm{M}$ $\mathrm{Cr}(\mathrm{VI})$. This suggests the combination of carbon source and chromate was necessary for cell death to occur which indicates cells were more susceptible when metabolically active. As previously mentioned, the uptake of ethanol may increase the uptake of $\mathrm{Cr}(\mathrm{VI})$ and contribute to the toxicity observed.

\section{CONCLUSIONS}

Results of this study demonstrate that carbon metabolism affects Arthrobacter sp. LLW01 growth in the presence of $\mathrm{Cr}(\mathrm{VI})$ and the subsequent reduction of $\mathrm{Cr}(\mathrm{VI})$ which would have detrimental effects on bioremediation efforts involving this organism. While it is possible to limit the intentional addition of ethanol and butyrate into the environment to stimulate $\mathrm{Cr}(\mathrm{VI})$ remediation, natural attenuation methods will likely fail if these carbon sources are the primary sources available. Therefore, successful $\mathrm{Cr}(\mathrm{VI})$ remediation by Arthrobacter sp. LLW01 would require the addition of sugars such as glucose and lactate while limiting the availability of alcohols and some organic acids such as ethanol and butyrate. Soil systems are complex and the role of other soil constituents cannot be overlooked. Additional studies are needed to incorporate other constituents that could affect $\mathrm{Cr}(\mathrm{VI})$ reduction to integrate these results into large-scale bioremediation strategies. The results presented here should be useful in developing in situ bioremediation strategies and in understanding how Arthrobacter spp. may affect these strategies. 


\section{Conflicts of interest}

None.

\section{Acknowledgements}

The authors would like to sincerely thank Brady Lee, William A. Apel, Adie Phillips, and Matthew Fields for their intellectual contributions and laboratory assistance to this research. Financial support was provided by the U.S. Department of Energy, Office of Science, Subsurface Biogeochemical Research Program Contracts \# DE-FG0206ER64206 and \# DE-AC07-05ID14517. Partial financial support was also provided by the Montana University System Research Initiative Contract \# 51040-MUSRI2015-05.

\section{Appendix A. Supplementary data}

Supplementary material related to this article can be found, in the online version, at doi:https://doi.org/10.1016/j.jhazmat.2018.05.020.

\section{References}

[1] T.M. Roane, I.L. Pepper, Microbial responses to environmentally toxic cadmium, Microb. Ecol, 38 (1999) 358-364.

[2] G. Benyehuda, J. Coombs, P. Ward, D. Balkwill, T. Barkay, Metal resistance among aerobic chemoheterotrophic bacteria from the deep terrestrial subsurface, Can. J. Microbiol. 49 (2003) 151-156.

[3] M. Megharaj, S. Avudainayagam, R. Naidu, Toxicity of hexavalent chromium and its reduction by bacteria isolated from soil contaminated with tannery waste, Curr. Microbiol. 47 (2003) 51-54.

[4] R.N. Horton, W.A. Apel, V.S. Thompson, P.P. Sheridan, Low temperature reduction of hexavalent chromium by a microbial enrichment consortium and a novel strain of Arthrobacter aurescens, BMC Microbiol. 6 (2006) 5-23.

[5] K.L. Henne, C.H. Nakatsu, D.K. Thompson, A.E. Konopka, High-level chromate resistance in Arthrobacter sp. strain FB24 requires previously uncharacterized accessory genes, BMC Microbiol. 9 (2009) 199-214.

[6] J.G. Moberly, A. Staven, R.K. Sani, B.M. Peyton, Influence of pH and inorganic phosphate on toxicity of zinc to Arthrobacter sp. isolated from heavy-metal-contaminated sediments, Environ. Sci. Technol. 44 (2010) 7302-7308.

[7] T. Naz, M.D. Khan, I. Ahmed, S. ur Rehman, E.S. Rha, I. Malook, M. Jamil, Biosorption of heavy metals by Pseudomonas species isolated from sugar industry, Toxicol. Ind. Health 32 (2016) 1619-1627.

[8] D. Barceloux, Chromium, Clin. Toxicol. 37 (1999) 173-194.

[9] M. Dsouza, M.W. Taylor, S.J. Turner, J. Aislabie, Genomic and phenotypic insights into the ecology of Arthrobacter from Antarctic soils, BMC Genomics 16 (2015) $1-18$.

[10] C. Hagedorn, J.G. Holt, A nutritional and taxonomic survey of Arthrobacter soil solates, Can. J. Microbiol. 21 (1975) 353-361.

[11] N.V. Asatiani, M.K. Abuladze, T.M. Kartvelishvili, N.G. Bakradze, N.A. Sapojnikova, N.Y. Tsibakhashvili, L.V. Tabatadze, L.V. Lejava, L.L. Asanishvili, H.Y. Holman, Effect of chromium(VI) action on Arthrobacter oxydans, Curr. Microbiol. 49 (2004) 321-326.

[12] C. Quintelas, V.B. da Silva, B. Silva, H. Figueiredo, T. Tavares, Optimization of production of extracellular polymeric substances by Arthrobacter viscosus and their interaction with a 13X zeolite for the biosorption of $\mathrm{Cr}(\mathrm{VI})$, Environ. Technol. 32 (2011) 1541-1549.

[13] Y. Li, Q. Li, Y. Fengying, J. Bao, Z. Hu, W. Zhu, Y. Zhao, Z. Lin, Q. Dong, Chromium (VI) detoxification by oxidation and flocculation of exopolysaccharides from Arthrobacter sp. B4, Int. J. Biol. Macromol. 81 (2015) 235-240.

[14] A. Yassi, Carcinogenicity of chromium compounds, in: E. Nieboer, J. Niragu, E. Niebaer (Eds.), Chromium in the Natural and Human Environments, Wiley \& Sons, New York, 1988, pp. 443-478.

[15] S. Dey, A. Paul, Evaluation of chromate reductase activity in the cell-free culture filtrate of Arthrobacter sp. SUK 1201 isolated from chromite mine overburden, Chemosphere 156 (2016) 69-75.

[16] G.W. Sewall, H. Shen, P.H. Pritchard, Chromium (VI) Biotreatment in Soil, in, United States Environmental Protection Agency, (1997).

[17] B. Fonseca, M. Pazos, T. Tavares, M. Sanromán, Removal of hexavalent chromium of contaminated soil by coupling electrokinetic remediation and permeable reactive biobarriers, Environ. Sci. Pollut. Res. 19 (2012) 1800-1808.

[18] A. Bafana, K. Krishnamurthi, M. Patil, T. Chakrabarti, Heavy metal resistance in Arthrobacter ramosus strain G2 isolated from mercuric salt-contaminated soil, J. Hazard. Mater. 177 (2010) 481-486.
[19] B.A.N.A. Silva, H. Figueiredo, I.C. Neves, M. Tavares, The role of pH on $\mathrm{Cr}(\mathrm{VI})$ reduction and removal by Arthrobacter viscosus, Int. J. Chem. Biol. Eng. 2 (2009) $100-103$

[20] F. Camargo, F. Bento, B. Okeke, W. Frankenberger, Chromate reduction by chromium-resistant bacteria isolated from soils contaminated with dichromate, J. Environ. Qual. 32 (2003) 1228-1233.

[21] K.P. Nickens, S.R. Patierno, S. Ceryak, Chromium genotoxicity: a double-edged sword, Chem.-Biol. Interact. 188 (2010) 276-288.

[22] B. James, The challenge of remediating chromium-contaminated soil, Environ. Sci. Technol. 30 (1996) 248-251.

[23] S.A. Eichorst, C.R. Kuske, Identification of cellulose-responsive bacterial and fungal communities in geographically and edaphically different soils by using stable isotope probing, Appl. Environ. Microbiol. 78 (2012) 2316-2327.

[24] M.J. Swift, O.W. Heal, J.M. Anderson, Decomposition in Terrestrial Ecosystems, Univ of California Press, Blackwell Publishing, 1979.

[25] M.O. Gessner, C.M. Swan, C.K. Dang, B.G. McKie, R.D. Bardgett, D.H. Wall, S. Hättenschwiler, Diversity meets decomposition, Trends Ecol. Evol. 25 (2010) 372-380.

[26] M. Schutter, R. Dick, Shifts in substrate utilization potential and structure of soil microbial communities in response to carbon substrates, Soil Biol. Biochem. 33 (2001) 1481-1491.

[27] C.H. Nakatsu, N. Carmosini, B. Baldwin, F. Beasley, P. Kourtev, A. Konopka, Soil microbial community responses to additions of organic carbon substrates and heavy metals ( $\mathrm{Pb}$ and Cr), Appl. Environ. Microbiol. 71 (2005) 7679-7689.

[28] P.S. Kourtev, C.H. Nakatsu, A. Konopka, Responses of the anaerobic bacterial community to addition of organic C in chromium(VI)- and iron(III)-amended microcosms, Appl. Environ. Microbiol. 72 (2006) 628-637.

[29] A.G. Tekerlekopoulou, G. Tsiamis, E. Dermou, S. Siozios, K. Bourtzis, D.V. Vayenas, The effect of carbon source on microbial community structure and $\mathrm{Cr}(\mathrm{VI})$ reduction rate, Biotechnol. Bioeng. 107 (2010) 478-487.

[30] K. Reddy, T. Cutright, Nutrient amendment for the bioremediation of a chromiumcontaminated soil by electrokinetics, Energy Sour. 25 (2003) 931-943.

[31] M. Ziagova, A. Koukkou, M. Liakopoulou-Kyriakides, Optimization of cultural conditions of Arthrobacter sp. Sphe3 for growth-associated chromate(VI) reduction in free and immobilized cell systems, Chemosphere 95 (2014) 535-540.

[32] S. Dey, A. Paul, Hexavalent chromium reduction by aerobic heterotrophic bacteria indigenous to chromite mine overburden, Braz. J. Microbiol. 44 (2013) 307.

[33] E. Cardenas, W.-M. Wu, M.B. Leigh, J. Carley, S. Carroll, T. Gentry, J. Luo, D. Watson, B. Gu, M. Ginder-Vogel, Microbial communities in contaminated sediments, associated with bioremediation of uranium to submicromolar levels, Appl. Environ. Microbiol. 74 (2008) 3718-3729.

[34] N.N. North, S.L. Dollhopf, L. Petrie, J.D. Istok, D.L. Balkwill, J.E. Kostka, Change in bacterial community structure during in situ biostimulation of subsurface sediment cocontaminated with uranium and nitrate, Appl. Environ. Microbiol. 70 (2004) 4911-4920.

[35] A.C. Somenahally, J.J. Mosher, T. Yuan, M. Podar, T.J. Phelps, S.D. Brown, Z.K. Yang, T.C. Hazen, A.P. Arkin, A.V. Palumbo, Hexavalent chromium reduction under fermentative conditions with lactate stimulated native microbial communities, PloS One 8 (2013) e83909.

[36] E.L. Brodie, D.C. Joyner, B. Faybishenko, M.E. Conrad, C. Rios-Velazquez, J. Malave, R. Martinez, B. Mork, A. Willett, S. Koenigsberg, Microbial community response to addition of polylactate compounds to stimulate hexavalent chromium reduction in groundwater, Chemosphere 85 (2011) 660-665.

[37] D.M. Akob, L. Kerkhof, K. Küsel, D.B. Watson, A.V. Palumbo, J.E. Kostka, Linking specific heterotrophic bacterial populations to bioreduction of uranium and nitrate in contaminated subsurface sediments by using stable isotope probing, Appl. Environ. Microbiol. 77 (2011) 8197-8200.

[38] P. Lara, E. Morett, K. Juárez, Acetate biostimulation as an effective treatment for cleaning up alkaline soil highly contaminated with $\mathrm{Cr}(\mathrm{VI})$, Environ. Sci. Pollut. Res. (2016) 1-9.

[39] J.K. Fredrickson, J.M. Zachara, D.L. Balkwill, D. Kennedy, S.W. Li, H.M. Kostandarithes, M.J. Daly, M.F. Romine, F.J. Brockman, Geomicrobiology of high-level nuclear waste-contaminated vadose sediments at the Hanford Site, Washington State, Appl. Environ. Microbiol. 70 (2004) 4230-4241.

[40] E.K. Field, S. D'Imperio, A.R. Miller, M.R. VanEngelen, R. Gerlach, B.D. Lee, W.A. Apel, B.M. Peyton, Application of molecular techniques to elucidate the influence of cellulosic waste on the bacterial community structure at a simulated lowlevel-radioactive-waste site, Appl. Environ. Microbiol. 76 (2010) 3106-3115.

[41] Anonymous, 2000. The Current and Planned Low-Level Waste Disposal Capacity Report Revision 2, in: U.S.D.o. Energy (Ed.).

[42] Anonymous, 2002. Historical description of RWMC surrogate buried waste test pits for environmental restoration waste area group 7 OU 7-13/14, in: I.N. Laboratory (Ed.).

[43] S.B. Leschine, Cellulose degradation in anaerobic environments, Ann. Rev. Microbiol. 49 (1995) 399-426.

[44] I. Chew, J. Obbard, R. Stanforth, Microbial cellulose decomposition in soils from a rifle range contaminated with heavy metals, Environ. Pollut. 111 (2001) 367-375.

[45] L.R. Lynd, P.J. Weimer, W.H. van Zyl, I.S. Pretorius, Microbial cellulose utilization: fundamentals and biotechnology, Microbiol. Mol. Biol. Rev. 66 (2002) 739.

[46] M.R. VanEngelen, E.K. Field, R. Gerlach, B.D. Lee, W.A. Apel, B.M. Peyton, $\mathrm{UO}_{2}{ }^{2+}$ 
speciation determines uranium toxicity and bioaccumulation in an environmental Pseudomonas sp. isolate, Environ. Toxicol. Chem. 29 (2010) 763-769.

[47] R.M. Atlas, Handbook of Microbiological media, CRC Press, Boca Raton, FL, 2004.

[48] D.H. Nies, S. Koch, S. Wachi, N. Peitzsch, M.H. Saier Jr., CHR, a novel family of prokaryotic proton motive force-driven transporters probably containing chromate/ sulfate antiporters, J. Bacteriol. 180 (1998) 5799-5802.

[49] J. Nyman, F. Caccavo, A. Cunningham, R. Gerlach, Biogeochemical elimination of chromium (VI) from contaminated water, Bioremed. J. 6 (2002) 39-55.

[50] S. Viamajala, B. Peyton, R. Gerlach, V. Sivaswamy, W. Apel, J. Petersen, Permeable reactive biobarriers for in situ $\mathrm{Cr}(\mathrm{VI})$ reduction: bench scale tests using Cellulomonas sp. strain ES6, Biotechnol. Bioeng. 101 (2008) 1150-1162.

[51] L. Giotta, A. Agostiano, F. Italiano, F. Milano, M. Trotta, Heavy metal ion influence on the photosynthetic growth of Rhodobacter sphaeroides, Chemosphere 62 (2006)
1490-1499.

[52] M.R. VanEngelen, R.K. Szilagyi, R. Gerlach, B.D. Lee, W.A. Apel, B.M. Peyton, Uranium exerts acute toxicity by binding to pyrroloquinoline quinone cofactor, Environ. Sci. Technol. 45 (2011) 937-942.

[53] S.I. Shupack, The chemistry of chromium and some resulting analytical problems, Environ. Health Perspect. 92 (1991) 7-11.

[54] R.K. Tokala, D. Yonge, G.J. Puzon, V. Sivaswamy, L. Xun, B.M. Peyton, Subsurface mobility of organo-Cr(III) complexes formed during biological reduction of $\mathrm{Cr}(\mathrm{VI})$, J. Environ. Eng. 134 (2008) 87-92.

[55] G.J. Puzon, A.G. Roberts, D.M. Kramer, L. Xun, Formation of soluble organo - chromium(III) complexes after chromate reduction in the presence of cellular organics, Environ. Sci. Technol. 39 (2005) 2811-2817. 